\title{
Diketopiperazines from Alternaria dauci
}

\author{
Martha Leyte-Lugo ${ }^{1, *}$, Pascal Richomme ${ }^{2}$, Luis M. Peña-Rodriguez ${ }^{1}$ \\ ${ }^{1}$ Unidad de Biotecnología, Centro de Investigación Científica de Yucatán, Mérida, Yucatán 97205, Mexico. \\ ${ }^{2}$ Universite' d'Angers, UPRES EA921 SONAS, SFR 4207 QUASAV, Angers, France.
}

*Corresponding author: Martha Leyte-Lugo, email: : mleyte@correo.xoc.uam.mx

Received March 26 ${ }^{\text {th }}, 2020$; Accepted August $14^{\text {th }}, 2020$.

DOI: http://dx.doi.org/10.29356/jmcs.v64i4.1228

\begin{abstract}
Alternaria dauci is the causal agent of Alternaria leaf blight (ALB), a foliar disease of carrot crops (Daucus carota) around the world. In terms of phytotoxic metabolites production, $A$. dauci has received limited attention. Previous studies carried out on the secondary metabolites involved in the pathogenicity of this fungus have only reported the isolation of a ubiquitous non-selective phytotoxin known as zinniol. Because of this, the aim of this research is directed towards the isolation and identification of secondary metabolites involved in the plant-pathogen interaction process. A. dauci was cultured in the Czapek-Dox medium, and the culture filtrate was extracted with ethyl acetate. The leaf-spot assay of fractions resulting from the partition process showed a phytotoxic effect in the ethyl acetate fraction. The chromatographic separation of ethyl acetate fraction allowed the isolation of seven diketopiperazines, identified as cyclo-(pro-val) (1), cyclo-(pro-leu) (2), cyclo-(pro-phe) (3), cyclo-(val-leu) (4), cyclo-(val-phe) (5), cyclo-(leu-phe) (6) and cyclo-(leu-tyr) (7). The structures of the different metabolites were established by comparing their spectroscopic $\left({ }^{1} \mathrm{H}\right.$ NMR) and spectrometric (GC-MS) data with those reported in the literature.
\end{abstract}

Keywords: Daucus carota; Alternaria dauci; phytopathogen; phytotoxicity; diketopiperazine.

Resumen. Alternaria dauci es el agente causal del tizón de la hoja (ALB), una enfermedad foliar que afecta los cultivos de zanahoria (Daucus carota) alrededor del mundo. En términos de producción de metabolitos fitotóxicos, $A$. dauci ha recibido una atención muy limitada. Estudios previos llevados a cabo sobre los metabolitos secundarios involucrados en la patogenicidad de este hongo, solo han reportado el aislamiento de una fitotoxina no selectiva y ubicua conocida como zinniol. Debido a lo anterior, el objetivo de esta investigación se dirige al aislamiento e identificación de metabolitos secundarios implicados en la interacción planta-patógeno. Para esto el fitopatógeno se cultivó en medio Czapek-Dox y el filtrado del cultivo se extrajo con acetato de etilo. La evaluación de las fracciones resultantes de la partición, en el ensayo de manchas foliares en hojas, mostró un efecto fitotóxico en la fracción de acetato de etilo. La separación cromatográfica de la fracción de acetato de etilo permitió el aislamiento de siete dicetopiperazinas identificadas como ciclo-(pro-val) (1), ciclo-(pro-leu) (2), ciclo-(pro-phe) (3), ciclo-(val-leu) (4), ciclo-(val-phe) (5), ciclo-(leu-phe) (6) y ciclo(leu-tyr) (7). Las estructuras de los diferentes metabolitos se establecieron comparando sus datos espectroscópicos (1H RMN) y espectrométricos (CG-EM) con los reportados en la literatura.

Palabras clave: Daucus carota; Alternaria dauci; fitopatógeno; fitotoxicidad; dicetopiperazina. 


\section{Introduction}

The Alternaria genus, widely distributed and commonly found in the soil and organic matter is known for its pathogenicity against many important crops worldwide [1,2]. To the date, a wide variety of different metabolites have been reported from Alternaria fungal cultures, and these include terpenoids, pyranones, quinones, phenolics, and nitrogen-containing metabolites [1]. The isolated metabolites are reported to exhibit several biological activities, including phytotoxic, cytotoxic, and antimicrobial, which suggest their potential application in different areas such as chemistry, pharmacy, and agriculture.

Many secondary metabolites produced by Alternaria spp. are known to be responsible for their pathogenicity, these metabolites are known as phytotoxins. Examples of these phytotoxins include the cyclodepsipeptides destruxins A and B produced by A. linicola [3,4]; tenuazonic acid, a nitrogen-containing metabolite, isolated from A. alternata [5]; zinniol, a phenolic phytotoxin commonly identified in extracts from many Alternaria spp., including A. carthami, A. cichorii, A. cirsinoxia, A. dauci, A. macrospora, A. porri, A. solani, A. tagetica, and A. zinniae [1, 6-10]; and maculosin, a diketopiperazine reported from A. alternata [11].

One Alternaria species that has received limited attention, in terms of its secondary metabolites production, is Alternaria dauci, the causal agent of Alternaria leaf blight (ALB), a foliar disease of carrot crops (Daucus carota) around the world $[12,13]$. The disease appears initially in the leaves as small greenish-brown lesions, becoming larger and turning dark-brown, often surrounded by a chlorotic halo [14]. The main effects associated with the disease are the reduction of leaf photosynthetic activity and carbohydrate production, followed by separation of necrotic foliage from the taproot. These effects contribute to a significant reduction in harvesting efficiency [12]. Previous studies carried out on the metabolites produced by $A$. dauci have reported the identification of alternariol and alternariol monomethyl ether, together with the ubiquitous non-host selective phytotoxin zinniol $[15,16]$. However, Lecomte et al. [13] demonstrated that zinniol is not responsible for the phytotoxic effect caused by the organic extract of $\mathrm{A}$. dauci, since the pure phytotoxin proved to be not toxic towards carrot embryogenic cultures and the UHPLC-MS analysis of the fungal organic extract did not show significant amounts of this phytotoxin in the chromatographic profile. Here, as part of a project directed towards understanding the role of natural products in plant-pathogen interactions, we wish to report the isolation and identification of seven diketopiperazines from the culture filtrate of A. dauci, when cultured in Czapek-Dox medium.

\section{Experimental}

\section{General Experimental Procedures}

Nuclear Magnetic Resonance (NMR) spectra were recorded on a Varian/Agilent (AR Premium COMPACT) at $600(1 \mathrm{H})$ and $150 \mathrm{MHz}(13 \mathrm{C})$; chemical shifts were recorded as $\delta$ values. Gas ChromatographyMass Spectrometry (GC-MS) were analyzed by an Agilent (Santa Clara, CA, USA) 6890N gas chromatograph coupled to an Agilent 5975C INERT mass spectrometer detector. High-Performance Liquid Chromatography (HPLC) was carried out using a Waters Alliance ${ }^{8}$ HPLC system equipped with a 2998-photodiode array detector (PDA). Control of the equipment, data acquisition, processing, and management of chromatography was performed by the Empower 2 software program (Waters) (version 3). UV spectra were measured with a 2998-photodiode array UV detector (PDA). Analytical HPLC was performed using a Phenomenex-Luna RPC18 column $(150 \times 4.6 \mathrm{~mm}, 5 \mu \mathrm{m}$ particle size $)$ used as the stationary phase at a $1.0 \mathrm{~mL} / \mathrm{min}$ flow rate. Semipreparative HPLC was performed using a Phenomenex-Luna RP-C18 column $(250 \times 10.0 \mathrm{~mm}, 5 \mu \mathrm{m}$ particle size) with a $2.3 \mathrm{~mL} / \mathrm{min}$ flow rate. Column chromatography (CC) was carried out on a Silica gel $60 \AA$ (70-230 mesh ASTM) (Merck KGaA. Darmstadt, Germany). Thin-layer chromatography (TLC) analyses were carried out on silica gel 60 F254 plates (Merck KGaA. Darmstadt, Germany) using phosphomolybdic acid as a color reagent. 


\section{Fungal Material}

The reference strain of $A$. dauci (FRA017) used in this investigation was isolated in 2000 from naturally infected carrot leaves collected in Gironde, France; fungal structures isolated from lesions were confirmed as $A$. dauci based on conidial morphology and molecular analysis using the elongation factor $1 \alpha$ (EF-1 $\alpha$ ) and ITS sequences [12]. The fungal strain FRA017 has been deposited in the Institut de Recherche en Horticulture et Semences (IRHS) in Angers, France. For the production of conidia, A. dauci (FRA017) was grown on V8 juice agar medium [200 mL V8 vegetable juice (HERDEZ ${ }^{\circledR}$ ), $3 \mathrm{~g} \mathrm{CaCO}_{3}, 15 \mathrm{~g} \mathrm{agar} \mathrm{L}^{-1}$, $\mathrm{pH}^{6.8}$ ], and incubated at $24 \pm 2{ }^{\circ} \mathrm{C}$ for 20 days under natural light conditions.

\section{Fungal Growth Conditions}

Fernbach flasks containing $1 \mathrm{~L}$ of Czapek-Dox liquid medium [1.5 g of potassium nitrate (SigmaAldrich $^{\circledR}$ ), $0.5 \mathrm{~g}$ of potassium chloride (Fermont), $0.5 \mathrm{~g}$ of magnesium sulfate (Sigma-Aldrich ${ }^{\circledR}$ ), $0.01 \mathrm{~g}$ of ferric sulfate (Sigma-Aldrich ${ }^{\circledR}$ ), $1.0 \mathrm{~g}$ of monobasic potassium phosphate (J.T. Baker ${ }^{\circledR}$ ), $6 \mathrm{~g}$ of sucrose (commercial brand), and $2.0 \mathrm{~g}$ of casein (Sigma Aldrich ${ }^{\circledR}$ ) in $1 \mathrm{~L}$ of distilled water, with final $\mathrm{pH}$ 6.0] were inoculated with a conidial suspension adjusted to $1 \times 10^{4}$ conidia $\mathrm{mL}^{-1}$ of $\mathrm{A}$. dauci. Fungal cultures were grown at room temperature $\left(25^{\circ} \mathrm{C}\right)$, under shake $(100 \mathrm{rpm})$ conditions, for 96 hours.

\section{Extraction, Isolation and Purification}

The mycelia and culture filtrates from a $15 \mathrm{~L}$ culture of $A$. dauci were separated by filtration through cheesecloth. The aqueous culture filtrate was extracted with ethyl acetate (three times, 2:1, v/v), and the organic layer was evaporated in vacuo, yielding $432.5 \mathrm{mg}$ of extract (ca. $45 \mathrm{mg} \mathrm{L}^{-1}$ ). A portion of the organic crude extract (ca. $420 \mathrm{mg}$ ) was suspended in $50 \mathrm{~mL}$ of a 95:5 mixture of water/methanol, and the resulting suspension was partitioned successively between hexane $(3 \times 50 \mathrm{~mL})$ and ethyl acetate $(3 \times 50 \mathrm{~mL})$, to produce three fractions: hexane $(\mathbf{A} ; 43.8 \mathrm{mg})$, ethyl acetate $(\mathbf{B} ; 202.7 \mathrm{mg})$ and aqueous $(\mathbf{C} ; 132.6 \mathrm{mg})$. The ethyl acetate fraction (B) was subjected to column chromatography eluting with mixtures of hexane-dichloromethanemethanol to yield sixteen semipurified fractions (B1-B16). Reverse-phase High-Performance Liquid Chromatography (HPLC) purification (Phenomenex-Luna RP-C18 $250 \times 10.0 \mathrm{~mm}$ column; $2.3 \mathrm{~mL} \mathrm{~min}^{-1}$ ) of fractions B6 to B9, and B12, using gradient elution from $10 \%$ to $90 \%$ aqueous acetonitrile for 20 minutes, resulted in the isolation of the seven diketopiperazines.

cyclo-(pro-val) (1): white powder (1.1 mg, 0.25\%); UV (PDA, $\left.\mathrm{CH}_{3} \mathrm{CN} / \mathrm{H}_{2} \mathrm{O}\right) \lambda_{\max } 203 \mathrm{~nm} ;{ }^{1} \mathrm{H}$ NMR $\left(600 \mathrm{MHz}, \mathrm{CD}_{3} \mathrm{OD}\right) \delta 4.20(1 \mathrm{H}, \mathrm{dd}, J=8.4,6.6 \mathrm{~Hz}, \mathrm{H}-6), 4.04(1 \mathrm{H}, \mathrm{s}, \mathrm{H}-3), 3.56(1 \mathrm{H}, \mathrm{m}, \mathrm{H}-9), 3.51$ (1H, m, H-9), 2.49 (1H, m, H-7), 2.32 (1H, m, H-10), 2.02 (1H, m, H-8), 1.94 (1H, m, H-7 and H-8), 1.09 (3H, d, J= $\left.7.2 \mathrm{~Hz}, \mathrm{CH}_{3}-11\right), 0.94$ (3H, d, $J=6.6 \mathrm{~Hz}, \mathrm{CH}_{3}-11$ '); ${ }^{13} \mathrm{C} \mathrm{NMR}\left(150 \mathrm{MHz}, \mathrm{CD}_{3} \mathrm{OD}\right) \delta 172.6(\mathrm{C}-2), 167.6(\mathrm{C}-5)$, 61.5 (C-6), 60.0 (C-3), 46.2 (C-9), 29.9 (C-10), 29.5 (C-7), 23.3 (C-8), 18.8 (C-11), 16.7 (C-11'); EIMS m/z $196[\mathrm{M}]+(5), 154\left(\mathrm{C}_{7} \mathrm{H}_{10} \mathrm{~N}_{2} \mathrm{O}_{2}, 100\right), 125\left(\mathrm{C}_{6} \mathrm{H}_{7} \mathrm{NO}_{2}, 44\right), 70\left(\mathrm{C}_{4} \mathrm{H}_{8} \mathrm{~N}^{+}, 82\right)$.

cyclo-(pro-leu) (2): white powder (0.6 mg, 0.14\%); UV (PDA, $\left.\mathrm{CH}_{3} \mathrm{CN} / \mathrm{H}_{2} \mathrm{O}\right) \lambda_{\max } 200 \mathrm{~nm}$; ${ }^{1} \mathrm{H} \mathrm{NMR}$ (400 MHz, CD 3 OD) $\delta 4.26(1 \mathrm{H}, \mathrm{t}, J=7.6 \mathrm{~Hz}, \mathrm{H}-6), 4.13(1 \mathrm{H}, \mathrm{m}, \mathrm{H}-3), 3.51(2 \mathrm{H}, \mathrm{dd}, J=8.6,4.8 \mathrm{~Hz}, \mathrm{H}-9), 2.31$ (1H, m, H-7), 2.01 (2H, m, H-8 and H-10), 1.90 (3H, m, H-7, H-8 and H-10), $1.52(1 \mathrm{H}, \mathrm{t}, J=8.0 \mathrm{~Hz}, \mathrm{H}-11)$, $0.97\left(3 \mathrm{H}, \mathrm{d}, J=6.4 \mathrm{~Hz}, \mathrm{CH}_{3}-12\right), 0.96\left(3 \mathrm{H}, \mathrm{d}, J=6.4 \mathrm{~Hz}, \mathrm{CH}_{3}-12{ }^{\prime}\right) ;{ }^{13} \mathrm{C}$ NMR $\left(100 \mathrm{MHz}, \mathrm{CD}_{3} \mathrm{OD}\right) \delta 172.8(\mathrm{C}-$ 2), 168.9 (C-5), 60.3 (C-6), 54.7 (C-3), 46.4 (C-9), 39.4 (C-10), 29.1 (C-7), 25.8 (C-11), 23.7 (C-8), 23.3 (C12), 22.2 (C-12'); EIMS m/z $210[\mathrm{M}]^{+}(5), 154\left(\mathrm{C}_{7} \mathrm{H}_{10} \mathrm{~N}_{2} \mathrm{O}_{2}, 100\right), 125\left(\mathrm{C}_{6} \mathrm{H}_{9} \mathrm{~N}_{2} \mathrm{O}^{+}, 18\right), 86\left(\mathrm{C}_{5} \mathrm{H}_{12} \mathrm{~N}^{+}, 71\right), 70$ $\left(\mathrm{C}_{4} \mathrm{H}_{8} \mathrm{~N}^{+}, 69\right)$.

cyclo-(pro-phe) (3): white powder (1.1 mg, 0.25\%); UV (PDA, $\left.\mathrm{CH}_{3} \mathrm{CN} / \mathrm{H}_{2} \mathrm{O}\right) \lambda_{\max } 203$ and $257 \mathrm{~nm}$; ${ }^{1} \mathrm{H}$ NMR (600 MHz, CD $\left.3 \mathrm{OD}\right) \delta 7.27$ (5H, m, H-2' H-6'), 4.45 (1H, dd, $\left.J=5.4,4.8 \mathrm{~Hz}, \mathrm{H}-6\right), 4.07$ (1H, dd, $J=$ 10.8, $6.6 \mathrm{~Hz}, \mathrm{H}-3), 3.54$ (1H, m, H-9), 3.37 (1H, m, H-9), 3.17 (2H, t, J=4.8, $3.6 \mathrm{~Hz}, \mathrm{H}-10), 2.10$ (1H, m, H7), $1.80(2 \mathrm{H}, \mathrm{m}, \mathrm{H}-7$ and $\mathrm{H}-8), 1.23(1 \mathrm{H}, \mathrm{m}, \mathrm{H}-8)$; EIMS m/z $244[\mathrm{M}]^{+}(40), 153\left(\mathrm{C}_{7} \mathrm{H}_{9} \mathrm{~N}_{2} \mathrm{O}_{2}, 33\right), 125$ $\left(\mathrm{C}_{5} \mathrm{H}_{4} \mathrm{~N}_{2} \mathrm{O}_{2}, 100\right), 91\left(\mathrm{C}_{7} \mathrm{H}_{7}, 51\right), 70\left(\mathrm{C}_{4} \mathrm{H}_{8} \mathrm{~N}^{+}, 40\right)$.

cyclo-(val-leu) (4): white powder (1.2 mg, 0.28\%); UV (PDA, $\left.\mathrm{CH}_{3} \mathrm{CN} / \mathrm{H}_{2} \mathrm{O}\right) \lambda_{\max } 203 \mathrm{~nm}$; ${ }^{1} \mathrm{H} \mathrm{NMR}$ $\left(600 \mathrm{MHz}, \mathrm{CD}_{3} \mathrm{OD}\right) \delta 3.95(1 \mathrm{H}, \mathrm{dd}, J=4.8,4.2 \mathrm{~Hz}, \mathrm{H}-6), 3.77(1 \mathrm{H}, \mathrm{dd}, J=4.2,1.2 \mathrm{~Hz}, \mathrm{H}-3), 2.23(1 \mathrm{H}, \mathrm{m}, \mathrm{H}-$ 7), 1.87 (1H, m, H-9), 1.75 (1H-m, H-10), $1.61(1 \mathrm{H}, \mathrm{m} \mathrm{H}-9), 1.05$ (3H, dd, J=6.6, $\left.1.8 \mathrm{~Hz}, \mathrm{CH}_{3}-8\right), 0.97$ (3H, dd, $\left.J=7.2,1.8 \mathrm{~Hz}, \mathrm{CH}_{3}-8^{\prime}\right), 0.96\left(3 \mathrm{H}, \mathrm{dd}, J=7.2,1.8 \mathrm{~Hz}, \mathrm{CH}_{3}-11\right), 0.96\left(3 \mathrm{H}, \mathrm{dd}, J=6.6,1.8 \mathrm{~Hz} \mathrm{CH}_{3}-11^{\prime}\right)$; EIMS $m / z 170\left(\mathrm{C}_{8} \mathrm{H}_{14} \mathrm{~N}_{2} \mathrm{O}_{2}, 27\right), 156\left(\mathrm{C}_{7} \mathrm{H}_{12} \mathrm{~N}_{2} \mathrm{O}_{2}, 100\right), 113\left(\mathrm{C}_{6} \mathrm{H}_{11} \mathrm{NO}, 59\right), 72\left(\mathrm{C}_{5} \mathrm{H}_{9}, 50\right)$. 
cyclo-(val-phe) (5): white powder (1.2 mg, 0.28\%); UV (PDA, $\left.\mathrm{CH}_{3} \mathrm{CN} / \mathrm{H}_{2} \mathrm{O}\right) \lambda_{\max } 203$ and $258 \mathrm{~nm}$; ${ }^{1} \mathrm{H}$ NMR (600 MHz, CD 3 OD) $\delta 7.25\left(5 \mathrm{H}, \mathrm{m}, \mathrm{H}-22^{\prime} \sim \mathrm{H}-6{ }^{\prime}\right), 4.31(1 \mathrm{H}, \mathrm{t}, J=5.4,4.8 \mathrm{~Hz}, \mathrm{H}-3), 3.65(1 \mathrm{H}, \mathrm{d}, J=4.8$ $\mathrm{Hz}, \mathrm{H}-6), 3.23(1 \mathrm{H}, \mathrm{dd}, J=13.8,5.4 \mathrm{~Hz}, \mathrm{H}-9), 3.04(1 \mathrm{H}, \mathrm{dd}, J=13.8,4.8 \mathrm{~Hz}, \mathrm{H}-9), 1.65(1 \mathrm{H}, \mathrm{m}, \mathrm{H}-7), 0.80$ $(3 \mathrm{H}, \mathrm{dd}, J=7.2,1.8 \mathrm{~Hz}, \mathrm{H}-8), 0.44\left(3 \mathrm{H}, \mathrm{dd}, J=7.2,1.8 \mathrm{~Hz}, \mathrm{H}-8\right.$ '); EIMS $m / z 246[\mathrm{M}]+(42), 127\left(\mathrm{C}_{5} \mathrm{H}_{7} \mathrm{~N}_{2} \mathrm{O}_{2}\right.$, 58), 91 (46), $91\left(\mathrm{C}_{7} \mathrm{H}_{7}, 100\right)$.

cyclo-(leu-phe) (6): white powder $\left(1.3 \mathrm{mg}, 0.30 \%\right.$ ); UV (PDA, $\left.\mathrm{CH}_{3} \mathrm{CN} / \mathrm{H}_{2} \mathrm{O}\right) \lambda_{\max } 203$ and $257 \mathrm{~nm}$; ${ }^{1} \mathrm{H}$ NMR $\left(600 \mathrm{MHz}, \mathrm{CD}_{3} \mathrm{OD}\right) \delta 7.25\left(5 \mathrm{H}, \mathrm{m}, \mathrm{H}-2^{\prime} \sim \mathrm{H}-6{ }^{\prime}\right), 4.31(1 \mathrm{H}, \mathrm{t}, J=4.8,3.6 \mathrm{~Hz}, \mathrm{H}-3), 3.66(1 \mathrm{H}, \mathrm{dd}, J=$ 4.8, 4.2 Hz, H-6), 3.29 (1H, dd, $J=3.6 \mathrm{~Hz}, \mathrm{H}-10), 2.95(1 \mathrm{H}, \mathrm{dd}, J=4.8 \mathrm{~Hz}, \mathrm{H}-10), 1.43(1 \mathrm{H}, \mathrm{m}, \mathrm{H}-8), 0.87$ (1H, m, H-7), 0.73 (3H, dd, $J=7.2,0.6 \mathrm{~Hz}, \mathrm{H}-9), 0.69(3 \mathrm{H}, \mathrm{dd}, J=7.8,0.6 \mathrm{~Hz}, \mathrm{H}-10), 0.08$ (1H, m, H-7); EIMS $m / z 260[\mathrm{M}]+(22), 204\left(\mathrm{C}_{11} \mathrm{H}_{12} \mathrm{~N}_{2} \mathrm{O}_{2}, 40\right), 141\left(\mathrm{C}_{8} \mathrm{H}_{15} \mathrm{NO}, 52\right), 113\left(\mathrm{C}_{4} \mathrm{H}_{5} \mathrm{~N}_{2} \mathrm{O}_{2}, 44\right), 91\left(\mathrm{C}_{7} \mathrm{H}_{7}, 100\right)$.

cyclo-(leu-tyr) (7): white powder ( $0.8 \mathrm{mg}, 0.19 \%)$; $\mathrm{UV}\left(\mathrm{PDA}, \mathrm{CH}_{3} \mathrm{CN} / \mathrm{H}_{2} \mathrm{O}\right) \lambda_{\max } 203,225$ and 275 $\mathrm{nm} ;{ }^{1} \mathrm{H}$ NMR (600 MHz, CD $\left.3 \mathrm{OD}\right) \delta 7.00\left(2 \mathrm{H}, \mathrm{dd}, J=8.3,1.8 \mathrm{~Hz}, \mathrm{H}-2^{\prime}\right.$ and $\left.6{ }^{\prime}\right), 6.71(2 \mathrm{H}, \mathrm{dd}, J=8.3,1.8 \mathrm{~Hz}$, H-3' and $\left.5^{\prime}\right), 4.23(1 \mathrm{H}, \mathrm{t}, J=3.6 \mathrm{~Hz}, \mathrm{H}-3), 3.66(1 \mathrm{H}, \mathrm{dd}, J=9.6,4.2 \mathrm{~Hz}, \mathrm{H}-6), 3.20(1 \mathrm{H}, \mathrm{dd}, J=13.8,3.6 \mathrm{~Hz}$, $\mathrm{H}-10), 2.83(1 \mathrm{H}, \mathrm{dd}, J=13.8,3.6 \mathrm{~Hz}, \mathrm{H}-10), 1.44(1 \mathrm{H}, \mathrm{m}, \mathrm{H}-8), 0.89(1 \mathrm{H}, \mathrm{m}, \mathrm{H}-7), 0.76(3 \mathrm{H}, \mathrm{d}, J=6.0 \mathrm{~Hz}$, $\left.\mathrm{CH}_{3}-9\right), 0.74\left(3 \mathrm{H}, \mathrm{d}, J=6.6 \mathrm{~Hz}, \mathrm{CH}_{3}-9^{\prime}\right), 0.13(1 \mathrm{H}, \mathrm{m}, \mathrm{H}-7)$; EIMS m/z $276[\mathrm{M}]+(8), 170\left(\mathrm{C}_{8} \mathrm{H}_{14} \mathrm{~N}_{2} \mathrm{O}_{2}, 96\right)$, $107\left(\mathrm{C}_{7} \mathrm{H}_{7} \mathrm{O}, 100\right), 70\left(\mathrm{C}_{5} \mathrm{H}_{9}, 90\right)$.

\section{Leaf-spot assay}

Parsley (Petroselinum crispum) leaves were excised and washed with water. A $20 \mu \mathrm{L}$ drop of the sample $(5.0 \mathrm{mg} / \mathrm{mL}$ for extracts and fractions), non-inoculated medium (negative control), or sterile distilled water (blank), was placed over a lightly scratched area made with a sterile, trimmed paintbrush on the adaxial face of the leaf. The leaves were kept in a high humidity chamber under natural light. Three leaves, with two applications each, were used for each treatment [16].

\section{Results and discussion}

The culture filtrate of A. dauci was separated from the mycelial mat and extracted with ethyl acetate, and the resulting crude extract was partitioned with solvents of increasing polarity to produce three fractions that were subjected to biological evaluation. Evaluation of the phytotoxic activity of the extract and the different fractions using the leaf-spot assay, which has been shown to be an effective method to identify phytotoxic bioactive fractions and pure metabolites, showed strong activity in the medium polarity (ethyl acetate, B) fraction. Column chromatography purification of the phytotoxic fraction $\mathbf{B}$, followed by semipreparative HPLC purification of the resulting phytotoxic fractions $\mathbf{B 6}$ and $\mathbf{B 7}$, yielded three diketopiperazines in pure form: cyclo(pro-val) (1), cyclo-(pro-leu) (2) and cyclo-(pro-phe) (3). Similar semipreparative HPLC purification of fractions B8, B9, and B12 allowed the purification of four additional diketopiperazines: cyclo-(val-leu) (4), cyclo-(val-phe) (5), cyclo-(leu- phe) (6), and cyclo-(leu-tyr) (7) (Fig. 1). The GC-MS analysis of 1 showed a single component with a parent ion peak at $m / z 196$, corresponding to a molecular formula of $\mathrm{C}_{10} \mathrm{H}_{16} \mathrm{~N}_{2} \mathrm{O}_{2}$. The nature of the two nitrogen atoms in the structure 1 was established from its ${ }^{13} \mathrm{C}$ NMR spectrum which showed the characteristic amide carbonyls of a piperazine-2,5-dione at $\delta_{\mathrm{C}} 172.6$ and 167.6 [17], together with two methine signals at $\delta_{\mathrm{C}} 61.5$ and $60.0 \mathrm{ppm}$ corresponding to the $\mathrm{sp}^{3}$ carbons bonded to nitrogen [18]. The low field chemical shift of the methine proton signals $\left(\delta_{\mathrm{H}} 4.20\right.$ and 4.04) in the ${ }^{1} \mathrm{H}$ NMR spectrum of 1 further confirmed them being on a nitrogen-bonded carbon, $a$ to a carbonyl group. Comparing this data, including additional signals in the ${ }^{1} \mathrm{H}$ and ${ }^{13} \mathrm{C}$ NMR spectra corresponding to three methylenes $\left(\delta_{\mathrm{C}} / \delta_{\mathrm{H}} 46.2,29.5\right.$ and 23.3 / 3.54, 2.49 and 2.02) and two methyl groups $\left(\delta_{\mathrm{C}} / \delta_{H} 18.8\right.$ and $16.7 / 1.09$ and 0.94$)$, with those reported in the literature allowed the identification of $\mathbf{1}$ as cyclo-(pro-val) [19,20], a bicyclic diketopiperazine isolated from Aspergillus ochraceus and Oopsra destructor [19] and recently reported from marine sponge-associated bacteria [21]. 
<smiles>CC([18F])C1NC(=O)C2CCCN2C1=O</smiles>

1<smiles>CC(C)CC1NC(=O)C2CCCN2C1=O</smiles>

2<smiles>CC(C)CC1NC(=O)C(C(C)C)NC1=O</smiles>

4<smiles>CC(C)C1NC(=O)C(Cc2ccccc2)NC1=O</smiles>

5<smiles>O=C1NC(Cc2ccccc2)C(=O)N2CCCC12</smiles>

3<smiles>CC(C)C[C@H]1NC(=O)[C@H](Cc2ccccc2)NC1=O</smiles>

6<smiles>CC(C)CC1NC(=O)C(Cc2ccc(O)cc2)NC1=O</smiles>

Fig. 1. Diketopiperazines identified from the crude extract of $\mathrm{A}$. dauci

The ${ }^{1} \mathrm{H}$ and ${ }^{13} \mathrm{C}$ NMR spectra of $\mathbf{2}$ proved to be very similar to that of $\mathbf{1}$, the only difference being the presence of a two-proton signal at $\delta_{\mathrm{H}} 2.01$ and 1.90 in ${ }^{1} \mathrm{H}$ NMR spectrum of 2, indicating the presence of an extra methylene group in the side chain. This was confirmed by the parent ion peak at $m / z 210$ observed in the GC-MS analysis of 2, allowing its identification as cyclo-(pro-leu); final confirmation came from comparing the spectroscopic data of $\mathbf{2}$ with those reported in the literature [20,22]. The ${ }^{1} \mathrm{H}$ NMR spectrum of $\mathbf{3}$ showed the characteristic signals of a diketopiperazine, together with signals for a mono-substituted aromatic ring and a two-proton signal corresponding to benzylic methylene; comparing this data with those reported in the literature allowed the identification of $\mathbf{3}$ as cyclo-(pro-phe) [20,23]. Diketopiperazines $\mathbf{5}-\mathbf{7}$ showed similar spectroscopic data to those of 1-3 and were identified based on their MS and ${ }^{1} \mathrm{H}$ NMR data as cyclo-(val-leu) (4), cyclo-(valphe) (5), cyclo-(leu-phe) (6) and cyclo-(leu-tyr) (7) [23-25].

The seven diketopiperazines isolated from the phytotoxic ethyl acetate fraction of the culture filtrate of $A$. dauci have been previously reported from different microorganisms. Diketopiperazines 1-4 have recently been reported from culture supernatants of Pseudomona aeruginosa, $P$. fluorescens, $P$. putida, $P$. alcaligenes, Proteus mirabilis, Enterobacter agglomerans, Vibrio vulnificus, and Citrobacter freundii [26]. While, cyclo(val-phe) (5) was isolated from a culture of a marine bacteria found in marine sediments and is reported to enhance the plasticity of various axonal populations, suggesting that it may stimulate spinal cord repair by 
promoting compensatory sprouting of spinally projecting axons [27]. Similarly, diketopiperazines 1-3 were isolated from the co-culture of sponge-associated Actinomycetes, Actinokineospora sp., and Nocardiopsis sp. Cyclo-(leu-phe) (6) was isolated from roasted coffee [24]; diketopiperazines 3 and $\mathbf{7}$ have been reported from Callyspongia sp., and cyclo-(leu-tyr) (7) has been reported to stimulate MCP-1 (monocyte chemoattractant protein-1) $[21,28]$.

Diketopiperazines are recognized as an important class of biologically active natural products, with a potential application in drug discovery and development because of their diverse pharmaceutical effects, including antibacterial, antifungal and antiviral [29-31] as well as different types of biological activities such as cytotoxic [32], free radical scavenging [33,34], quorum-sensing signaling regulation [23,26], and plantgrowth promotion [35,36]. Most importantly, several diketopiperazines have been shown to be phytotoxic, including (L-trp-L-val) isolated from the blackleg fungus Phoma lingam [37]; and exserohilone and dihydroexserohilone produced by Exserohilum holm [38]; the thaxtomins, a group of phytotoxins characterized as 4-nitroindol-3-yl-containing 2,5-dioxopiperazines, produced by plant-pathogenic bacteria of the genus Streptomyces that cause the common scab disease of potato [37,39], and have been shown to cause cell swelling, reduce seedling growth, and inhibit cellulose synthesis in plants [40]; and maculosin [cyclo(L-Tyr-L-Pro)], the first host-specific fungal phytotoxin produced by a weed pathogen, causing necrotic lesions on spotted knapweed (Centaurea maculosa) [11,38]. Even though the limited amounts of material prevented evaluation of the isolated diketopiperazines 1-7 in the leaf spot assay, three of the diketopiperazines isolated during this investigation, namely cyclo-(pro-val) (1), cyclo-(pro-leu) (2), and cyclo-(pro-phe) (3), have been previously reported as phytotoxic metabolites $[9,22,41]$. Finally, considering the fact that previously reported phytotoxic diketopiperazines have been identified as having the L, L configuration, it is possible that metabolites $\mathbf{1}, \mathbf{2}$, and $\mathbf{3}$, obtained from fractions having phytotoxic activity, might correspond to the same isomers.

\section{Conclusion}

This is the first report of diketopiperazines, a completely different class of metabolites produced by Alternaria dauci, which could be involved in the plant-pathogen interaction between carrot plants and the phytopathogen.

\section{Acknowledgments}

Financial support from Région Pays de la Loire and SEP-CONACYT-ANUIES-ECOS-NORD

(México-France) collaborative Project No. 276520 is gratefully acknowledged.

\section{References}

1. Lou, J.; Fu, L.; Peng, Y.; Zhou, L. Molecules 2013, 18, 5891-5935.

2. Narain, U.; Kant, S.; Chand, G., in: Crop Diseases and Their Management - Integrated Approaches, Chand, G., Kumar, S., Eds. CRC Press, Boca Raton, FL, USA, 2016.

3. Evans, N.; Mcroberts, N.; Hill, R.A.; Marshall, G. Ann Appl Biol, 1996, 129, 415-431. DOI: https://doi.org/10.1111/j.1744-7348.1996.tb05765.x

4. Buchwaldt, L.; Green, H. Plant Pathol. 1992, 41, 55-63. DOI: https://doi.org/10.1111/j.13653059.1992.tb02316.x

5. Sanodiya, B.S.; Thakur, G.S.; Baghel, R.K.; Pandey, A.K.; Bhogendra, G.; Prasad, K.S.; Bisen, P.S. J. Plant Prot. Res. 2010, 50, 133-139. DOI: https://doi.org/10.2478/v10045-010-0023-3

6. Barash, I.; Mor, H.; Netzer, D.; Kashman, Y. Physiol. Plant Pathol. 1981, 19, 7-16. DOI: https://doi.org/10.1016/S0048-4059(81)80003-3 
7. Tietjen, K.G.; Schaller, E.; Matern, U. Physiol. Plant Pathol. 1983, 23, 387-400. DOI: https://doi.org/10.1016/0048-4059(83)90023-1

8. Cotty, P.J.; Misaghi, I.J. Phytopathology 1984, 74, 785-788. DOI: https://doi.org/10.1094/phyto-74$\underline{785}$

9. Stierle, A.; Hershenhorn, J.; Strobel, G. Phytochemistry 1993, 32, 1145-1149. DOI: https://doi.org/10.1016/S0031-9422(00)95080-5

10. Gamboa-Angulo, M.M.; Escalante-Erosa, F.; Garcia-Sosa, K.; Alejos-Gonzalez, F.; Delgado-Lamas, G.; Peña-Rodríguez, L.M. J. Agr. Food Chem. 2002, 50, 1053-1058. DOI: https://doi.org/10.1021/jf010641t

11. Stierle, A.C.; Cardellina II, J.H.; Strobel, G.A. Proc. Natl. Acad. Sci. 1988, 85, 8008-8011. DOI: https://doi.org/10.1073/pnas.85.21.8008

12. Boedo, C.; Benichou, S.; Berruyer, R.; Bersihand, S.; Dongo, A.; Simoneau, P.; Lecomte, M.; Briard, M.; Le Clerc, V.; Poupard, P. Plant Pathol. 2012, 61, 63-75. DOI: https://doi.org/10.1111/j.13653059.2011.02494.x

13. Lecomte, M.; Hamama, L.; Voisine, L.; Gatto, J.; Hélesbeux, J.J.; Séraphin, D.; Peña-Rodríguez, L.M.; Richomme, P.; Boedo, C.; Yovanopoulos, C.; Gyomlai, M.; Briard, M.; Simoneau, P.; Poupard, P.; Berruyer, R. PLoS One 2014, 9. DOI: https://doi.org/10.1371/journal.pone.0101008

14. Farrar, J.J.; Pryor, B.M.; Davis, R.M. Plant Dis. 2004, 88, 779-784. DOI: https://doi.org/10.1094/PDIS.2004.88.8.776

15. Freeman, G.G. Phytochemistry 1966, 5, 719-725. DOI: https://doi.org/10.1016/S00319422(00)83652-3

16. Qui, J.A.; Castro-Concha, L.A.; García-Sosa, K.; Miranda-Ham, M.L.; Peña-Rodríguez, L.M. J. Gen. Plant Pathol. 2010, 76, 94-101. DOI: https://doi.org/10.1007/s10327-010-0222-9

17. Chu, M.; Mierzwa, R.; Truumees, I.; Gentile, F.; Patel, M.; Gullo, V.; Chan, T.M.; Puar, M.S. Tetrahedron Lett. 1993, 34, 7537-7540. DOI: https://doi.org/10.1016/S0040-4039(00)60393-3

18. Elkahoui, S.; Rahim, H.A.; Tabbene, O.; Shaaban, M.; Limam, F.; Laatsch, H. Nat. Prod. Res. 2013, 27, 108-116. DOI: https://doi.org/10.1080/14786419.2012.660635

19. Kodaira, Y. Agric. Biol. Chem 1961, 25, 261-262. DOI: https://doi.org/10.1080/00021369.1961.10857803

20. Adamczeski, M.; Reed, A.R.; Crews, P. J. Nat. Prod. 1995, 58, 201-208. DOI: https://doi.org/10.1021/np50116a007

21. Dashti, Y.; Grkovic, T.; Abdelmohsen, U.R.; Hentschel, U.; Quinn, R.J. Mar. Drugs 2014, 12, 30463059. DOI: https://doi.org/10.3390/md12053046

22. Trigos, A.; Reyna, S.; Cervantes, L. Nat. Prod. Lett. 1995, 6, 241-246. DOI: https://doi.org/10.1080/10575639508043166

23. Degrassi, G.; Aguilar, C.; Bosco, M.; Zahariev, S.; Pongor, S.; Venturi, V. Curr. Microbiol. 2002, 45, 250-254. DOI: https://doi.org/10.1007/s00284-002-3704-y

24. Ginz, M.; Engelhardt, U.H. Eur. Food Res. Technol. 2001, 213, 8-11. DOI: https://doi.org/10.1007/s002170100322

25. Chen, M.Z.; Dewis, M.L.; Kraut, K.; Merritt, D.; Reiber, L.; Trinnaman, L.; Da Costa, N.C. J. Food Sci. 2009, 74, 100-105. DOI: https://doi.org/10.1111/j.1750-3841.2009.01062.x

26. Campbell, J.; Lin, Q.; Geske, G.D.; Blackwell, H.E. ACS Chem. Biol. 2009, 4, 1051-1059. DOI: https://doi.org/10.1021/cb900165y

27. Wong, J.W.J.; McPhail, L.T.; Brastianos, H.C.; Andersen, R.J.; Ramer, M.S.; O’Connor, T.P. Exp. Neurol. 2008, 214, 331-340. DOI: https://doi.org/10.1016/j.expneurol.2008.08.020

28. Chen, J.H.; Lan, X.P.; Liu, Y.; Jia, A.Q. Bioorg. Med. Chem. Lett. 2012, 22, 3177-3180. DOI: https://doi.org/10.1016/j.bmcl.2012.03.045

29. Hirsch, S.; Miroz, A.; McCarthy, P.; Kashman, Y. Tetrahedron Lett. 1989, 30, 4291-4294. DOI: https://doi.org/10.1016/S0040-4039(01)80713-9

30. Rhee, K.H. Int. J. Antimicrob. Agents 2004, 24, 423-427. DOI: https://doi.org/10.1016/j.ijantimicag.2004.05.005

31. Li, X.; Kim, S.K.; Nam, K.W.; Kang, J.S.; Choi, H.D.; Son, B.W. J.Antibiot. 2006, 59, 248-250. DOI: https://doi.org/10.1038/ja.2006.35 
32. Gomez-Monterrey, I.; Campiglia, P.; Carotenuto, A.; Stiuso, P.; Bertamino, A.; Sala, M.; Aquino, C.; Grieco, P.; Morello, S.; Pinto, A.; Ianelli, P.; Novellino, E. J. Med. Chem. 2008, 22, 2924-2932. DOI: https://doi.org/10.1021/jm7013056

33. Furukawa, T.; Akutagawa, T.; Funatani, H.; Uchida, T.; Hotta, Y.; Niwa, M.; Takaya. Y. Bioorgan. Med. Chem. 2012, 20, 2002-2009. DOI: https://doi.org/10.1016/j.bmc.2012.01.050

34. Shou Zheng, T.; Xiang, P.; Guoyong, L.; Li-Xing, Z.; Li-Hua, X.; Wen-Jun, L.; Yinggang, L. J. Agr. Food Chem. 2013, 61, 3006-3012. DOI: https://doi.org/10.1021/jf400718w

35. Cronan, J.M.; Davidson, T.R.; Singleton, F.L.; Colwell, R.R.; Cardellina, J.H. Nat. Prod. Lett. 1998, 11, 271-278. DOI: https://doi.org/10.1080/10575639808044959

36. Borthwick, A.D. Chem Rev. 2012, 112, 3641-3716. DOI: https://doi.org/10.1021/cr200398y

37. Pedras, M.S.C.; Smith, K.C.; Taylor, J.L. Phytochemistry 1998, 49, 1575-1577. DOI: https://doi.org/10.1016/s0031-9422(98)00271-4

38. Strobel, G.; Kenfield, D.; Bunkers, G.; Sugawara, F.; Clardy, J. Cell Mol. Life Sci. 1991, 47, 819-826. DOI: https://doi.org/10.1007/BF01922462

39. King, R.R.; Calhoun, L.A. Phytochemistry 2009, 70, 833-841. DOI: https://doi.org/10.1016/j.phytochem.2009.04.013

40. Scheible, W.R.; Fry, B.; Kochevenko, A.; Schindelasch, D.; Zimmerli, L.; Somerville, S.; Loria, R.; Somerville, C.R. Plant Cell 2003, 15, 1781-1794. DOI: https://doi.org/10.1105/tpc.013342

41. Trigos, A.; Reyna, S.; Gutierrez, M.L.; Sanchez, M. Nat. Prod. Lett. 1997, 11, 13-16. DOI: https://doi.org/10.1080/10575639708043751 